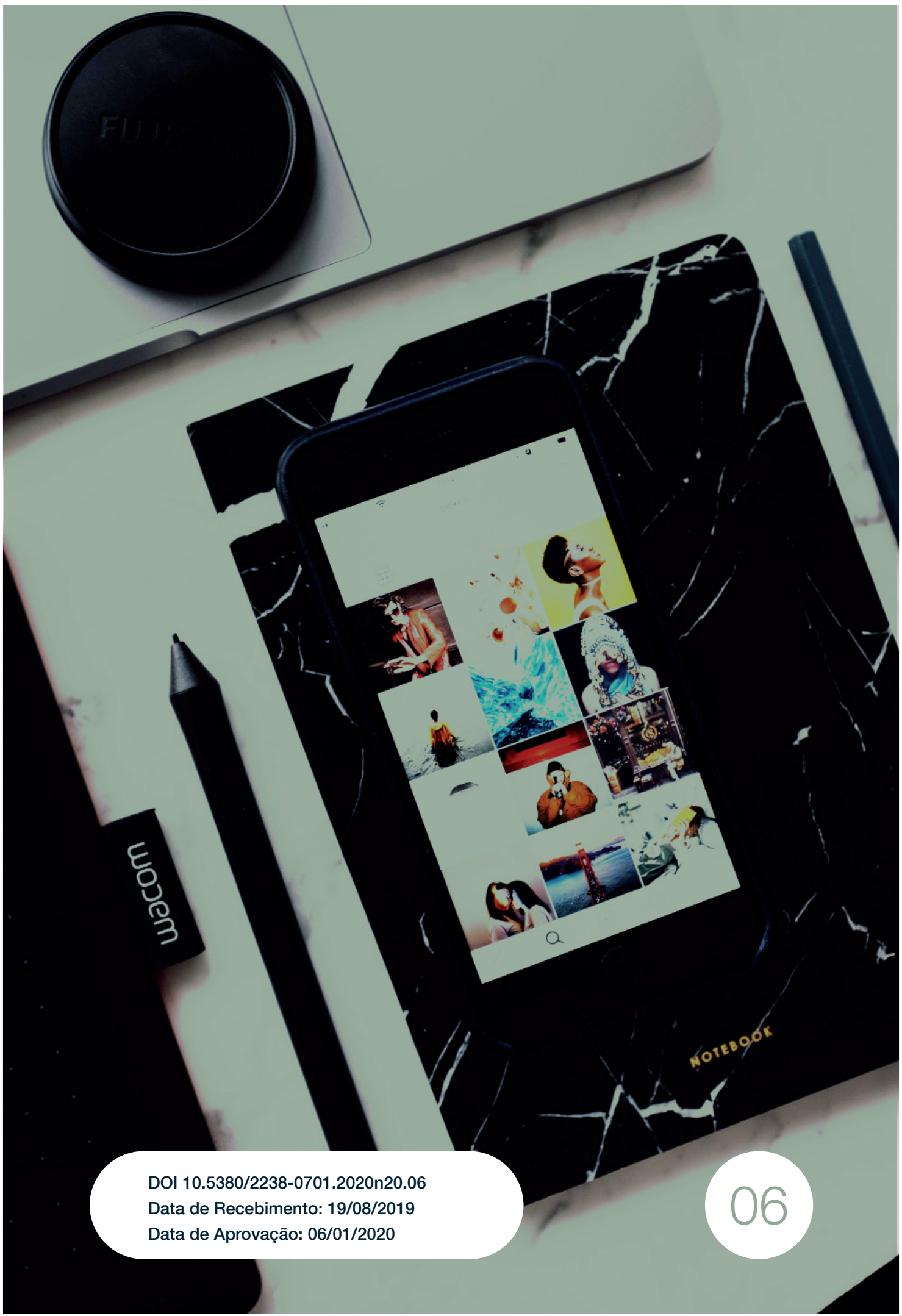


Redes sociais: a construção do conhecimento por meio de imagens 


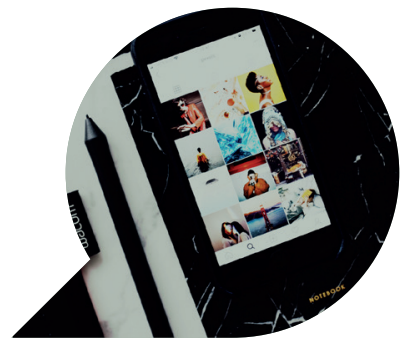

\section{Redes Sociais: A Construção Do Conhecimento Por Meio De Imagens}

\section{Social Networks: Construction Of Knowledge By Images}

\section{Redes Sociales: La Construcción Del Conocimento Por Medio De Imágenes}

\begin{tabular}{c}
\hline ELISABETE FREITAS TEIXEIRA $^{1}$ \\
\hline LUCIANA BACKES $^{2}$ \\
\hline
\end{tabular}

Resumo: O presente artigo emerge a partir da construção do conhecimento por meio de imagens fotográficas e suas representações compartilhadas na mídia social "Facebook" pelos alunos de fotografia. O problema se apresenta do seguinte modo: Quais as pistas encontradas na rede social a partir das imagens compartiIhadas para a construção do conhecimento? Os dados empíricos

\footnotetext{
1 Graduada pelo curso Tecnólogo em Fotografia pela Universidade Luterana do Brasil (2007/2), Especialização em Arte Contemporânea e Ensino da Arte (2009/1), Mestrado em Educação pelo Centro Universitário Unilasalle (2015/1) e doutorado pela mesma universidade (2018/2). Docente da Universidade Luterana do Brasil desde 2009 no curso de Tecnologia em Fotografia, Jornalismo e Publicidade e Propaganda.

2 Possui graduação em Pedagogia Habilitação Magistério e Séries Iniciais pela Universidade do Vale do Rio dos Sinos (1996), especialização em Informática na Educação pela Universidade Federal do Rio Grande do Sul (2002), mestrado em Educação pela Universidade do Vale do Rio dos Sinos (2007) e doutorado em Educação pela Universidade do Vale do Rio dos Sinos (2011) e Sciences de IEducation pela Université Lumière Lyon 2 (2011). Professora titular da Universidade La Salle - Canoas, Programa de Pós-Graduação em Educação. Líder do Grupo de Pesquisa Convivência e Tecnologia Digital na Contemporaneidade COTEDIC UNILASALLE/CNPq.
} 
observados a cada postagem foram submetidos a metodologia de análise do conteúdo na perspectiva da semiótica, conectando imagem, escrita e ampliação do conhecimento no processo criativo. As redes sociais viabilizaram a construção do conhecimento no compartilhar das imagens, fomentando a interação, os laços afetivos, as novas maneiras de perceber, ver, olhar, sentir, significar e representar não só pelo sujeito/autor, mas pelo "outro".

Palavras-chave: Redes Sociais; Conhecimento; Imagem.

Abstract: This article emerges from the construction of knowledge through photographic images and their representations shared on the social media "Facebook" by photography students. The problem is presented as it follows: What are the clues found in the social network from the shared images for the construction of knowledge? The empirical data observed in each post were submitted to the content analysis methodology from the perspective of semiotics, connecting the image, writing and knowledge expansion in the creative process. Social networks enabled the construction of knowledge in the sharing of images, fostering the interaction, the affective bonds, the new ways to perceive, to see, to look, to feel, to signify and to represent not only the by subject / author, but by the "other".

Keywords: Social Media; Knowledge; Image.

Resumen: El presente artículo emerge de la construcción del conocimiento por médio de imágenes fotográficas y sus representaciones compartidas por alunos de fotografia em la media social "Facebook". El problema se presenta del siguiente modo: ¿Cuáles son las pistas encontradas em la red social desde las imágenes compartidas para la construcción del conocimiento? Los datos empíricos observados a cada post fueron sometidos a la metodologia de análisis del contenido em la perspectiva de la semiótica, conectando imagen, escritura y ampliación del conocimiento em el comparto de imágenes, fomentando la intercción, los lazoz afectivos, las nuevas maneras de percibir, ver mirar, sentir, significar y representar, no sólo desde la perspectiva del sujeito/autor, 
sino desde el "outro".

Palabras-clave: Redes Sociales; Conocimiento; Imagen.

\section{Introdução}

A temática investigativa discute as possíveis pistas entre imagens, narrativas e interações compartilhadas em rede social para a construção do conhecimento pelos acadêmicos participantes da disciplina de Eventos Sociais do curso de Fotografia. Essa disciplina foi ministrada pela pesquisadora e configurada a partir da mídia social Facebook por meio da socialização e interação, constituindo laços afetivos no desenvolvimento das atividades realizadas na formação.

Esta mídia foi escolhida devido a sua relevância como linguagem e sua preferência pelos usuários na sociedade contemporânea, que assim têm tecido as redes da vida cotidiana, profissional e educativa, incentivando, contribuindo e fortalecendo as percepções e interações enquanto espelho social dos sujeitos/atores. Logo, a rede modela comportamentos, materializadas pelas tecnologias de informação, comunicação e suas interfaces. Além de tornar os sujeitos "vetores de experiências de aprendizagem", conforme sugere Paiva (2008).

Navegar por este espaço digital virtual nos permitiu construir conhecimentos, viver e conviver por meio de afetos, sentimentos e experiências que, além de fomentar a aprendizagem, contribuíram para a construção do perfil de cada participante. Assim, emergiram as representações do seu "eu" e suas performances no palco da vida cotidiana enquanto usuários midiáticos.

Para a reflexão, iniciamos com a caracterização das Redes Sociais, conduzida a partir da expansão da cultura virtual e do imaginário, construídos nas imagens e nas manifestações em seus compartilhamentos. Assim, enquanto construção do conhecimento são desencadeados processos de interação por meio de fotografias e narrativas escritas, fomentando a identificação com os "outros" acadêmicos do grupo, auferindo novas experiências, aprendizados e laços afetivos, potencializando o coletivo num "estar junto" e o perceber olhando para "si" e para o "outro". Em seguida, contemplamos a metodologia de pesquisa como proces- 
so de investigação da pesquisa e realizamos as análises das imagens relacionadas a temática redes sociais enquanto aprendizagem no fazer fotográfico, conectando os sujeitos/atores a novas reflexões e experiências, acompanhadas de suas respectivas narrativas, aludindo aos caminhos investigativos da semiótica conectados ao referencial teórico abordado. Finalizamos com as considerações sobre as pistas encontradas referentes à construção do conhecimento em redes sociais.

\section{A rede social: o "eu" e o "nós"}

Não há como mensurar a relevância das redes sociais no cotidiano contemporâneo, atribuímos seu desenvolvimento tecnológico aos meios de informação e comunicação e o seu desenvolvimento cultural à vida social em todos os contextos. Neste sentido, traçamos a trajetória de pesquisa em educação articulando a expansão da rede social a partir da cultura virtual com a chegada da Web preconizada pela internet, também chamada de teia do mundo. Esta cultura tem corroborado no fomento de transformação de forças tradicionais, potencializando as manifestações autorais e relações sociais pelo estudo das comunidades virtuais como forma mais pura de agregação e interação entre o sujeito, o objeto, o conhecimento e o ciberespaço.

Para Santaella (2003), o crescimento do consumo da rede define o que se entende por cultura das mídias, se desenvolvendo "no" e "pelo" ciberespaço. O ciberespaço reúne uma infinidade de mídias, bem como uma pluralidade de interfaces permitindo comunicação síncrona e assíncrona, enquanto a rede é todo o fluxo e as possíveis relações entre seus interlocutores. Desta forma, todo e qualquer signo "imagem" pode ser construído e socializado "no" e "pelo" ciberespaço, constituindo assim, um processo de comunicação em rede e uma nova cultura, chamada de cibercultura.

Este ciclo emerge no viver e conviver em contexto midiático, constituindo a cibercultura na construção de um "ambiente inédito que resulta da extensão das novas redes de comunicação para a vida social e cultural" (LÉVY, 1999, p. 12). Segundo Maffesoli (2001a, p. 69) estes são movimentos contemporâneos "do querer viver global" e "estar juntos", libertando o imaginário e o lúdico. Para o autor "o imaginário é alimentado 
por tecnologias", ultrapassando o indivíduo, que impregna o coletivo ou, ao menos, parte do coletivo. O imaginário estabelece vínculo. É cimento social. Logo, se o imaginário liga, une numa mesma atmosfera, não pode ser individual (MAFFESOLI, 2001a, p. 76).

Nesta articulação entre o viver e conviver em rede, concentra-se como proposição a criação da imagem, revolucionando seus modos de reprodução e de recepção, pois as transformações tecnológicas potencializam o conhecimento, por meio do "saber como fazer". A imagem torna-se uma testemunha, um signo que se relaciona com o seu produtor, narrando um momento de vida e carregando códigos visuais que permitem o conhecimento de nós mesmos, assim como a cultura e a representação que ela retrata. Produzir imagem é, antes de tudo, produzir interferência sobre os modos de olhar, de sentir e de compartilhar, torna-se um ato educativo por excelência, com forte impacto sobre o que já somos e o que ainda podemos vir-a-ser.

O compartilhar pode implicar na constituição do aspecto formativo desses sujeito/atores, influenciando a maneira de pensar, (re)fazer e representar. Transformando a percepção de mundo e de cada "eu" individual, tanto no sentido estético como intelectual, ou seja, práticas de transformação física, psicológica e sensível.

Entre criar imagens e compartilhar o sujeito/atores, atua como elemento dessa rede social, representados pelos nós, que são partes do sistema, de forma a moldar as estruturas sociais, através da interação e da constituição de laços sociais (RECUERO, 2009). Para Primo (2008), as interações moldam as estruturas sociais, não se caracterizam apenas por mensagens trocadas e ou pelos que se encontram em um dado contexto (geográfico, social, político, temporal), mas pelo relacionamento que proporciona, em um processo coletivo, que não pode ser manipulado unilateralmente ou pré-determinado. Logo, a comunicação estabelecida nesse processo de interação promove aprendizagem e experiências que tencionam as concepções da educação sobre os conhecimentos, significados, sentidos na vida social e a filtragem de informação relevante nas rotinas do cotidiano.

As estruturas sociais também são moldadas pelos laços, reciprocidade e confiança, assumindo um papel relevante em todos os campos sociais, seja na educação e na área do conhecimento, tanto visual como imagético. A reciprocidade é fundamentada por interação e vínculo, se 
concretizando a partir da expressão de sentimento após a troca e a confiança, de escolhas no nível interpessoal, que gera aos poucos reciprocidade. Os laços também podem ser definidos como fortes e fracos. Segundo Recuero (2009), os fortes são aqueles que englobam intimidade. Enquanto, os fracos são aqueles mais amplos, que envolvem "conhecidos" ou "contatos". Contudo, ambos dependem da interação para se estabelecer e alicerçar. Estes são movimentos que estimulam o "estar junto", comportamentos direcionados para preencher as expectativas, aceitação e aprovação, enquanto trocam experiências e se identificam com o "outro".

Aspectos que fomentam a construção de um "eu" que se dá na distância e aproximação existente entre diversos tipos de sujeitos/atores (identidade), configurando o espaço do "eu" pessoal, a construção da própria identidade. A identidade é a representação que um indivíduo dá a si mesmo por pertencer a um grupo. Nesse sentido, ela é o fruto da interação em contínua evolução, que se constrói por semelhança e também por oposição.

A identidade consiste em uma construção livre, não é a soma ou o resultado de um conjunto de experiências, mas um "vir a ser". E a imagem, nesta trama, torna-se uma testemunha, um signo que se relaciona com o seu produtor, narrando um momento de vida e carregando códigos visuais que permitem o conhecimento de nós mesmos, assim como a cultura e a representação que ela retrata. Nesse sentido, a (re)construção identitária é um permanente desafio no sentido de encontrar o equilíbrio entre aquilo que se é e o que os outros esperam que o sujeito/ ator seja. O outro da interação é o espelho social que permite ao sujeito/ ator reconhecer-se, avaliar-se e aprovar-se. O "eu" não existe, a não ser em interação com os outros.

As mídias proporcionam a elaboração de perfis individuais que irão operar como representações de "si" atuando como ferramenta para sua publicização. Recuero (2009) relaciona perfis ou "endereços" como um complexo de pistas do "eu", características a serem percebidas pelos outros usuários. Por isso, essas mídias apresentam uma formação identitária desses sujeitos/atores, externando suas interfaces e performances no palco da vida cotidiana. Sem a performance do usuário não existiria o "eu" do ciberespaço, em ambos os casos, as representações são construídas. 
Nessa lógica, intensifica-se a necessidade de estar conectado, de estar junto, de se legitimar para a aceitação do outro. Performances, comportamentos e relações que são construídas e fortalecidas culturalmente na interação, na confiança e nos laços afetivos configuram um tipo de teatro, constituindo um espaço simbólico e de representação metafórica da realidade social, enquanto desempenham papéis figurativos.

A partir destas conexões e interações, Putnam (2000) reafirma a formação do capital social como individual e/ou coletivo. Diz respeito ao indivíduo, a partir do momento que ele decide utilizar os recursos. É coletivo, porque faz parte das relações de um determinado grupo ou rede social e somente existe com ele. Assim, o sistema de interação mediada por computador proporcionado pelas redes sociais influencia diretamente no surgimento desse capital social, sintonizando o sujeito através da interação com o global, o local, o cotidiano, com o novo e o outro. Ao passo que, também contribui para a construção de um sujeito/ ator que ora se conecta e se inter-relaciona como usuário-consumidor.

\section{Caminho para refletir sobre as pistas na rede}

A partir da construção teórica fundamentada na investigação sobre o compartilhamento de imagens e narrativas nas mídias sociais, identificamos pistas que potencializam a constituição de redes. As pistas são identificadas no desenvolvimento da prática pedagógica desenvolvida na disciplina de Eventos Sociais, atrelando a teoria e a prática. A prática pedagógica contemplou encontros presenciais e on-line, diversas formas de comunicação e interação, assim como a plasticidade nas atividades - movimento e flexibilidade na construção das imagens.

Os dados empíricos foram constituídos a partir das postagens, compartilhamentos e interação do grupo fechado do Facebook, criado para os participantes da turma. Assim, por intermédio de práticas fotográficas, a técnica operou sobre os dados e os dados sobre a técnica, ou seja, a cada novo olhar, os alunos construíram um novo perceber, um novo sentir, uma nova representação imagética.

Cada postagem é composta pela narrativa do aluno sobre as percepções e aprendizagens da experiência, pela imagem construída e pelas interações nos comentários. As imagens representam o olhar em 
suas diversas formas de ver, viver e conviver em rede.

As análises ocorreram no trânsito entre o discurso imagético e o linguístico, sob a aplicação da semiótica, assim, a origem na sistematização da percepção, do objeto e do signo. Segundo Peirce (1931), a semiótica fundamenta a leitura de imagens e a comunicação pelo mundo imagético.

A teoria semiótica nos permite penetrar no próprio movimento in-
terno das mensagens, no modo como elas são engendradas, nos
procedimentos e recursos nelas utilizados. Permite-nos também
captar seus vetores de referencialidade, não apenas a um contexto
mais imediato, como também a um contexto estendido, pois em
todo o processo de signos ficam marcas deixadas pela história,
pelo nível de desenvolvimento das forças produtivas econômicas,
pela técnica e pelo sujeito que as produz (SANTAELLA, 2012, p. 5).

A leitura de imagens ocorreu em três passos: a significação, a referência e a interpretação. A significação consiste em contemplar a imagem. A referência discrimina, observa e objetiva a imagem. A interpretação examina os efeitos que os elementos provocam no intérprete, podendo conter ainda os conhecimentos do leitor sobre cada elemento da imagem que lê.

\section{Pistas desvendadas na rede}

Os acadêmicos caminharam ora como sujeitos, atores, narradores e coatores, assumindo o protagonismo do processo educativo, desempenhando papel relevante como aprendentes a cada tentativa aplicada na busca de uma nova construção fotográfica, representações não somente por erros e acertos, mas por desenvolvimento cognitivo e prático. De maneira criativa espelharam suas identidades - "eu" - a partir do olhar do "outro" - em interação. O Facebook, contribuiu para a construção do conhecimento, no compartilhamento das percepções, dos olhares e das experiências, propiciando fluxo de interação, por meio dos laços sociais. 


\section{Redes sociais: a performance do fotógrafo}

A partir do "perfil" do profissional e interagindo sobre "seu próprio aprimoramento" no mercado da fotografia, representa seu modo de "estar" em relação ao mundo e em relação aos "outros". Esse aprimoramento ocorre nas ações, na atitude ética — pensada a partir do "outro" como limite moral — e na estética — sensibilidade.

Quadro 01: Narrativa sobre a comunhão de elementos na aprendizagem

Diversas características que alguém que atua na fotografia e precisa absorver para seu aprimoramento. Furtividade, agilidade, preparação, criatividade, sensível. Procurou-se partir de alguns dos próprios adjetivos citados para representar analogias através da imagem, incluindo os elementos, cores e intensidades. A intensidade de algumas sombras buscando demonstrar o controle do fotógrafo sobre as mesmas e sobre as situações e oscilações as quais tem de se lidar. Os elementos podem ser associados de diversas formas, desde como uma base ou suporte até alguma referência a palco partindo do princípio de se criar uma certa espetacularização. Ainda nos elementos é possível notar o estado de alguns em comparação ao ambiente que de certa forma deveria interagir com ele, mas ele deve se manter "seco" e linear em relação a algumas hipóteses, ser capaz de absorver o necessário. Também pode-se interpretar essa última associação como alguém que expõe o que traz em seu interior, já que o fotógrafo e alguém que "fotografa com o que pensa e vive ou ainda mais alusivo com o que tem internamente". As cores, mais especificamente ao fundo podem ter uma interpretação meio distante, por particularmente serem alusivas ao renascimento de certa forma, pela ligação histórica do fotógrafo e da fotografia. 
Figura 01: Quem eu sou?!

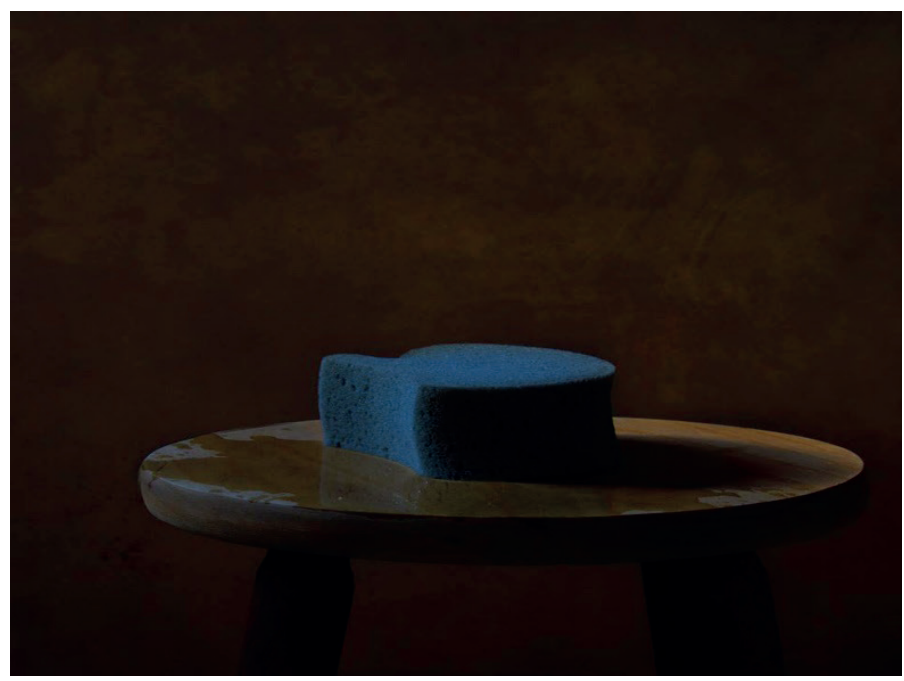

Fonte: Autor José.

Quadro 02: Comentários referentes ao post (figura 01)

\section{COMENTÁRIOS}

Professora Muito bem José encontraste muitas características sobre o perfil desse profissional, descreve aqui a relação da imagem construída com elas e o que te fez pensar nesse click exatamente assim com esse olhar!

Yuri esta imagem me faz pensar o que realmente somos e o que abstraímos do mundo, o quanto há dentro de cada um.

Camila sim como profissionais vamos absorvendo e aprendendo com as experiências.

José essa reflexão me deixou pensativo.

Professora quem ótimo José assim vamos construindo conhecimento nessa troca reflexiva de saberes.

Clara José é muito importante tu compartilhar conosco o porquê, assim a partir daquilo que estamos percebendo e vendo o nosso olhar ajudará a perceber diferentes formas, logo novas reflexões se formarão!

Adriano Como a esponja, temos um limite ao absorver as coisas à nossa volta, mas mesmo quando se desfaz o excesso, sempre acaba por sobrar alguma gota. Seja boa ou ruim. 
Maria Durante a leitura foi como se eu estivesse lendo um mapa conceitual onde todas as palavras e características se conectavam. A primeira vez que vi a fotografia me remeteu ao processo da nossa construção como fotógrafos, da capacidade de absorver visualmente e intangivelmente o universo. Não tinha lido o texto de como ele construiu a imagem a partir da ideia do perfil de fotógrafo e li várias vezes pra digerir. É interessante ver o ponto de vista e o processo de criação dele com a fotografia, o que ele queria representar e apresentar, e o quanto isso é diferente para mim e certamente para os outros colegas, são diferentes perspectivas.

Fonte: Grupo fechado do facebook.

As reflexões tensionadas sobre seu "eu" como sujeito e o modo como (con) vive com o "outro" na vida cotidiana: "esta imagem me faz pensar, o que realmente somos e o que abstraímos do mundo, o quanto há dentro de cada um", que constituem uma nova rede de relações com os outros: "professora e colegas essa reflexão me deixou pensativo".

Nessa rede de relações entre o "eu" e o "outro", o "eu" se constrói e se desconstrói a partir do "outro", e o "outro", na mesma via, se constrói a partir o "eu". Nas identificações, embora ambíguas, são igualmente recíprocas. Uma fruição evidenciada na narrativa "a primeira vez que vi a fotografia do José me remeteu ao processo da nossa construção como fotógrafos, da nossa capacidade de absorver visualmente e intangivelmente o universo, de transformar isso em fotografia". Essas interações no contexto tecnológico são promovidas devido ao fomento das conexões em redes sociais, chamada por Castells (2007) de "Sociedade em Rede", onde tudo e todos podem e devem estar interligados, produzindo sentidos, significados, representações e sentimentos. Logo a construção do conhecimento ocorre por meio da interação, no qual a acadêmica reflete a partir da imagem, "como a esponja, temos um limite ao absorver as coisas à nossa volta, mas mesmo quando se desfaz o excesso, sempre acaba por sobrar alguma gota. Seja boa ou ruim".

Conforme Agamben (2005), os seres viventes são aqueles que possuam algum modo ou capacidade de assimilar, conduzir, estabelecer, impedir, dominar e assegurar os movimentos, os comportamentos e/ou ainda pontos de vista. Por esse motivo "é interessante ver o ponto de vista e o processo de criação dele com a fotografia, o que ele queria representar e apresentar, e o quanto isso é diferente para mim e certamente para os outros colegas, são diferentes perspectivas". 
A interação é aquela ação que tem um reflexo comunicativo entre o sujeito/ator e os "outros" que fazem parte do meio. A narrativa conectada à imagem corroborou para refletir sobre as diferentes formas de percepção, representação e sentido no processo imaginário. Para Maffesoli (2001a), o imaginário se abastece de tecnologias, rompendo com as verdades absolutas, percorrendo por um espaço-tempo que ultrapassa os sujeitos/atores reverberando nessa condução, o viver e conviver no coletivo. No imaginário do grupo evidenciamos incertezas, medos, angústias, desejos, perspectivas e expectativas, assim como o "eu" individual, coletivo e profissional.

Falando sobre a formação do fotógrafo, um dos acadêmicos diz que "é muito importante sim tu compartilhar conosco o porquê, assim a partir daquilo que estamos percebendo e vendo, o nosso olhar ajudará a perceber diferentes formas, logo novas reflexões se formarão". A partir dessas reflexões observamos a relevância da diversidade do olhar, aproximação, sentimento de pertencimento e legitimação.

\section{Reflexões: "eu" sujeito, "eu" profissional e o cliente}

Observar a construção imagética desta acadêmica, sua narrativa escrita e interação entre os "outros", foi uma experiência que tocou a pesquisadora e o grupo significativamente. O "outro" é o sujeito principal do evento e a partir de sua presença constitui-se o espetáculo em uma nova sensibilidade que os conecta, abarcando a participação do sujeito/ ator individual num sujeito/ator coletivo (BAKTHIN, 1992). A acadêmica como participante em interação escolheu refletir sobre seu "eu" e o mercado da fotografia através da reprodução de sua imagem no espelho. 
Quadro 03: Narrativa sobre como estou me vendo no espelho

Há um conflito interno, onde eu tenho vontade de ser muitas coisas, mas acabo por não ser nenhuma. Seja por falta de estudo, de oportunidade, ou tempo, continuo sempre sonhando alto, mesmo sabendo que a probabilidade de dar certo, é bem pequena. Quando construí esta foto, eu estava bem decepcionada comigo mesma e com minha profissão. Ao mesmo tempo em que ser fotógrafo e criar imagens é empolgante, também é desanimador. Como crescer dentro de algo se você é só mais um? Como é possível ser feliz sendo coadjuvante? Muitas vezes penso em desistir e entrar de cabeça em outras coisas, mas mesmo que fotografia seja incerto e inviável, é o que posso fazer por mim e o que é mais certeiro. Viver é como um estalo de dedos. Eu preciso fazer algo por mim, pois posso acabar indo para a cova com minhas incertezas. É tudo sobre se arriscar.

Fonte: Grupo fechado Facebook.

Figura 02: Conflitos no espelho

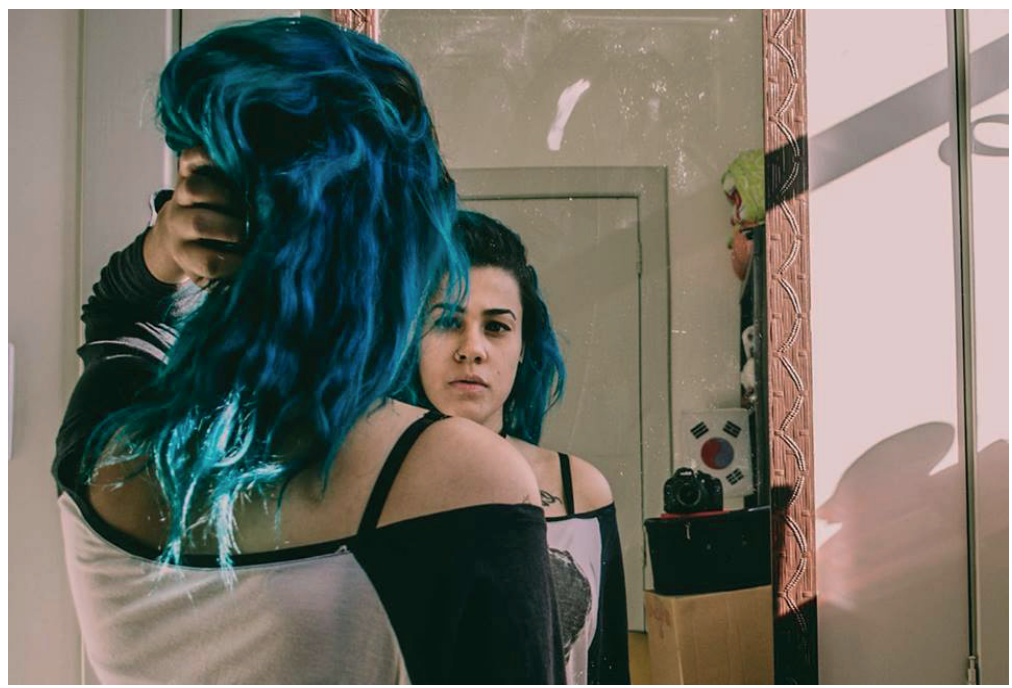

Fonte: Autora Ticiana 
Quadro 04: Comentários referentes ao post (figura 02)

\section{COMENTÁRIOS}

Professora Ticiana Relata como busca inspiração, como é tocado por intermédio da imagem.

Ticiana A inspiração vem para mim de formas muito diferentes. $O$ cinema é certamente o que mais me inspira, pois me identifico com uma série de cenas, cores e momentos que gostaria de reproduzir em imagens. $\mathrm{O}$ cheiro de um perfume, a melodia de uma música, as luzes noturnas da cidade. Isso varia muito, mas sempre penso em como produzir uma foto baseado no que sinto/ senti. Nesta semana, eu me encontro bem menos produtiva do que o normal. $\mathrm{E}$ quando meu estado de espírito está assim as ideias vem, mas vem com todas elas relacionadas a melancolia e nostalgia.

Maria Acho que a questão nem é ser feliz, e sim de aceitar que existe um valor muito forte nas coisas mais simples que a gente faz. Eu tenho medo de que fazer fotografia não dê certo, mas hoje eu quero fazer isso e é para isso que eu me entrego. Não para ser principal, e sim para ser eu fazendo algo que eu acho uma verdade que me completa e que engrandece a vida de quem acredita no que faço.

Dario Forte isso.

Ticiana Acho que sempre terei estes conflitos internos, afinal, eu não queria ser somente fotógrafa. Fotografia é uma coisa que eu amo muito, que eu sei que posso progredir na área, mas também tenho sonhos guardados que não vai ser seguidos por eu ser pé no chão demais, mas como a Maria falou, é isso que eu quero fazer e é para isso que estou me dedicando no momento.

Fonte: Grupo fechado Facebook.

A construção do conhecimento, a interação e as maneiras de olhar dos sujeitos/atores do grupo de pesquisa, ocorreu por meio de tensionamentos a partir da análise apresentada, o que nos conduz a uma reflexão apoiados em um recurso metafórico citado por Novaes (1993) chamado de o "jogo de espelhos". O autor abarca a imagem de "si" próprio a partir da forma como se percebe aos olhos do "outro", como se o olhar desse "outro" fosse um espelho refletindo sua imagem, revelando cada "outro" em um espelho e imagens diferentes.

A acadêmica manifesta que, a partir do modo como um grupo se vê refletido pelos olhos do "outro", no jogo de espelhos, cada imagem refletida está em correspondência com uma possibilidade de interação. 
Este movimento contribuiu para a elaboração de uma nova imagem, a cada nova imagem um novo aprendizado. Nesta perspectiva, é possível afirmar que cada sujeito/ator constrói sua própria "coleção de outros", configurações possíveis, selecionadas intencionalmente ou não (NOVAES, 1993).

Nessa "coleção de outros" o sujeito/ator se insere no contexto social, adaptando-se ao grupo, por meio de identificações — sentidos, paixões, emoções comuns, afetos - e constituindo seus modos de expressão identidade - em um processo inacabado, ambíguo, sendo um vir a ser ora individual e ora coletivo. Um "eu" representado pelo olhar que não é só dele, que é coautoral ou plural, que carrega a essência e a relação com "outro". Apoiada nessas representações, o sujeito/ator estabeleceu conexão interativa e social entre o "eu" individual e os "outros" como coletivo, enquanto participante e também como aprendente, mobilizando suas capacidades, habilidades e construindo saberes.

Na reflexão da acadêmica sobre seu "eu", ela destaca que "há um conflito interno, onde eu tenho vontade de ser muitas coisas, mas acabo por não ser nenhuma". Para ela "ser fotógrafo e criar imagens é empolgante, também é desanimador" e apesar de muitas incertezas e paradoxos é tocada por essa arte de maneira complexa. Observamos na interação a construção da imagem de "si" envolvendo uma "coleção de outros", um conjunto de visões que se refletem e se interpõem "acho que sempre terei estes conflitos internos". Como num jogo de espelhos, imagens e autoimagens se cruzam, permitindo constantes reflexões, ora pelas ambiguidades, ora pelas afinidades das imagens (NOVAES, 1993).

Neste processo, o "jogo de espelhos" instiga o desenvolvimento cognitivo do grupo, ou seja, aprendizado individual e compartilhamento de conhecimentos no coletivo, a partir do fluxo de interações na construção da imagem. A performance é narrada "eu sei que posso progredir na área, mas também tenho sonhos guardados que não vão ser seguidos por eu ser pé no chão demais, mas como a Carol falou, é isso que eu quero fazer e é para isso que estou me dedicando no momento". Os "sonhos" são refutados no seu imaginário "que não vão ser seguidos" por pensar ser muito segura, acaba por limitá-lo. Para Maffesoli (2001a), cada sujeito está apto a ler o imaginário com certa autonomia, porém, o que se vê é muito pouco individual, mas sobretudo grupal, comunitário, tribal, partilhado. Estabelecendo laços e unindo todos em uma mesma 
atmosfera "eu tenho medo de fazer fotografia e não dê certo, mas hoje eu quero fazer isso e é isso que eu me entrego". Nas representações há uma certa comunhão de ideias, que potencializaram a dilatação desse fluxo de interação, os acadêmicos passaram e estar ligados por meio de relatos sensibilizados e altruístas, colocando-se no lugar do "outro" ao compartilhar seus medos, anseios e sentimentos.

\section{Simulação de casamento: compartilhamentos e experiências}

"A simulação de casamento", um ritual organizado pelos sujeitos/ atores, desenvolvido com a participação de todos os elementos que esta cerimônia necessita. $\mathrm{O}$ evento envolve três fotógrafos e três assistentes de fotógrafos - todos componentes da disciplina, contemplando diversas possibilidades que a experiência proporciona enquanto percebem, olham, sentem e atuam como "eu" individual e ou "eu" coletivo. O ritual se repetiu diversas vezes, no entanto, a dinâmica foi invertida para que cada sujeito/ator vivesse a performance, do fotógrafo e do auxiliar, atribuindo significado em "como é ser um fotógrafo de casamento" e "como é ser assistente de casamento".

Quadro 05: Narrativa sobre compartilhar sentimentos na fotografia

Fotografar um turbilhão de sentimentos, sendo o mais importante, o amor entre o casal. Na primeira entrada da noiva já estava prestando atenção nos ângulos e momentos que gostaria de registrar, no que gostaria de transmitir, os enquadramentos e o que eu gostaria de apresentar em cada fotografia. * $A$ foto 1 representa o estar, em condições físicas ou emocionais, a mão entrelaçada de forma espontânea e com significado único no relacionamento. *A foto 2 foi provocada, pedi para que parassem durante a saída e se beijassem, o plano foi pensado. A minha intenção era apresentar o lugar que estavam e o motivo de estarem ali. Olhando o resultado das inúmeras fotografias que fiz eu senti que tinham espaços a serem preenchidos, por isso decidi que uni-las. A dupla exposição traz movimento e ela me instiga a querer ver além. Ela apresenta um detalhe e ao mesmo tempo a totalidade da situação. Não senti a necessidade de apresentar a face dos dois nas fotografias, pois o que os une vai além do semblante, é a ligação e a conexão que constroem juntos a cada dia. Tenho percebido que está cada vez mais simples o processo de compartilhar as fotos, de como aconteceu a construção e as minhas escolhas nos momentos que fotografamos. E a minha percepção sobre as fotos dos colegas tem sido maior, consigo identificar o olhar de cada um. E certamente 
ampliei o meu olhar com a fotografia de eventos e as possibilidades que tenho para criar.

Fonte: Grupo fechado facebook.

Figura 03: $\bigcirc$ compartilhar
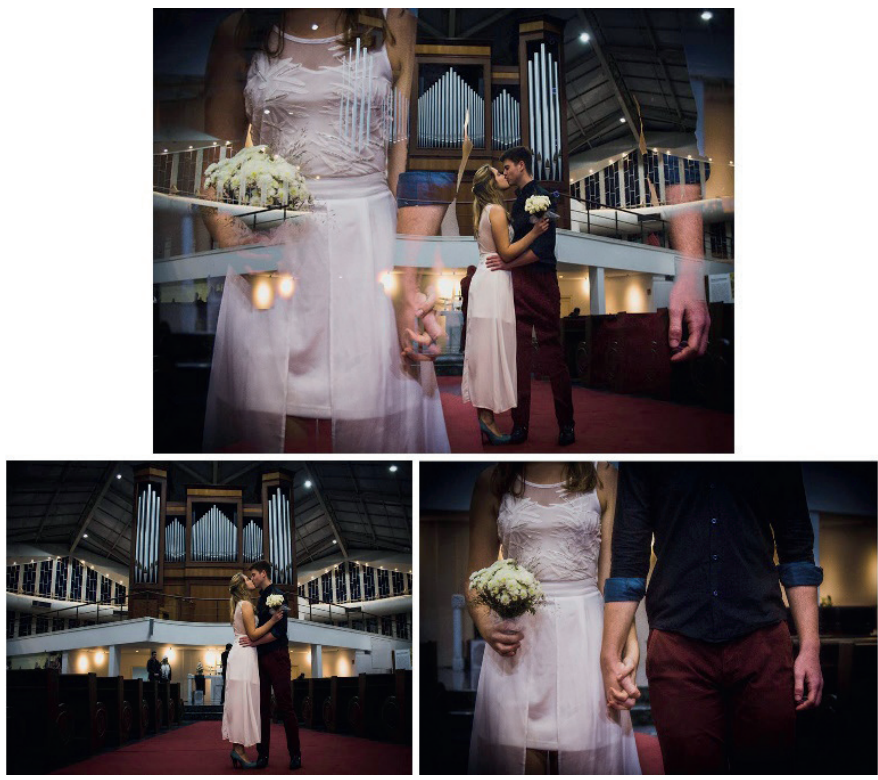

Fonte: Autora: Carol

Quadro 06: Comentários referentes ao post (figura 03)

COMENTÁRIOS

Rapha Carol amei o modo como tu construiu essas fotos. SIMPLESMEMTE DEMAIS.

Carol Ahhh que demais. Que bom que as fotos transmitiram para ti o que eu esperava

Helena Carol adorei tuas fotos, principalmente essa que tu construiu, simplesmente linda.

Maria A construção da foto me causou uma grande emoção, olhei a fotografia com um outro olhar, ela me tocou de alguma forma. 
Carol É especial que tu tenha sido tocada pela fotografia Professora Consigo perceber, sentir a tua sensibilidade aos detalhes $\underline{\text { Carol }} \odot$ Professora Carol compartilha conosco como está sendo para ti trocar todas essas experiências, dificuldades e ao mesmo tempo sensibilidade em forma de arte $^{*}$ Carol Consigo perceber a importância de compartilhar cada foto e a oportunidade de ter aulas práticas para desenvolver melhor o meu olhar. Também reconheço a identidade de cada colega com suas fotografias publicadas no grupo e a necessidade da interação como uma troca para desenvolvermos diferentes percepções juntos. E certamente ampliei o meu olhar com a fotografia de eventos e as possibilidades que tenho para criar no meio.

Professora Carol ótimo o teu desenvolvimento cognitivo...parabéns* Quais os colegas que compartilham resultados similares?

Fran Quanta sensibilidade,Essa construção de imagem enalteceu ainda mais a conexão do casal. Adorei!

Jéssica Gostei como ela trabalha com a dupla exposição, pode ser que para o cliente sim tenha o feito voltar no momento. Gosto de como compartilhamos nossos olhares aqui, como cada um aprende olhando e criticando a foto de cada colega.

Fonte: Grupo fechado facebook.

Surgiram inúmeras provocações nos compartilhamentos, inicialmente no espaço físico enquanto atuavam "na primeira entrada da noiva e já estava prestando atenção nos ângulos e momentos que eu gostaria de registrar, no que eu gostaria de transmitir, os enquadramentos e o que eu gostaria de apresentar em cada fotografia". Por meio da mídia social os estudantes utilizaram múltiplas linguagens para representar suas percepções e tirar a atenção de seus colegas discutindo aspectos que envolvem a atividade profissional. Um espaço que, segundo Recuero (2000), tornou-se um dos pontos mais importantes que a Internet proporciona, por reorganizar os hábitos de socialização. Assim, falando sobre as experiências, o estudante pontua: "Consigo perceber a importância de compartilhar cada foto e a oportunidade de ter aulas práticas para desenvolver melhor o meu olhar".

Experiências que se efetivam na rede social devido ao ciberespaço, ou seja, à materialização das tecnologias de informação, comunicação e suas interfaces. Uma rede de fluxos que possibilita possíveis relações entre os internautas, oportunizando o grupo em aprendizado a observar, analisar e interagir sobre as imagens e na narrativa da acadêmica. Ima- 
gens representadas por elementos carregados de sentido e sentimento de um "agora" pelo seu olhar criativo e único.

A primeira fotografia foi capturada de maneira espontânea, representando simbolicamente a cerimônia "o estar, em condições físicas ou emocionais, a mão entrelaçada de forma espontânea" e atribuindo significado aos sentimentos do momento, "com significado único no relacionamento", a fim de valorizar a força entre o casal retratado. Na segunda, sua construção foi planejada, em interação com os noivos, "pedi que parassem durante a saída e se beijassem, o plano foi pensado". A imagem foi composta por um olhar que objetivava apresentar um plano mais amplo — formato paisagem - "a minha intenção era apresentar o lugar que estavam e o motivo de estarem ali", dando a conotação estética para a ocasião. No entanto, a sua criação não representa suas intenções, "olhando o resultado das inúmeras fotografias que fiz eu senti que tinham espaços a serem preenchidos, por isso decidi que uni-las era a melhor opção". Para ressignificar sua criação transformou duas imagens em uma única, a fim de atribuir valor estético ao olhar a fotografia. Assim, através da "dupla exposição", uma técnica "que traz movimento e ela me instiga a querer ver além, apresenta um detalhe e ao mesmo tempo a totalidade da situação".

Suas imagens e narrativa provocaram fluxo de interação entre os "outros" sujeitos/atores, "a construção da foto me causou uma grande emoção, olhei a fotografia com um outro olhar, ela me tocou de alguma forma". Os colegas atribuíram a dupla exposição como se fosse uma marca do seu "eu", o que instigou o imaginário do grupo. A manipulação da imagem sobreposta desenvolveu novos conceitos estéticos nos colegas, a opacidade da imagem — transparência — os remeteu ao lúdico, ao fantasioso, ao sonho. Também mencionam a relevância das trocas enquanto compartilhamento em rede, propiciando ampliar o seu olhar sobre as imagens dos "outros" que não é a dele, "quanta sensibilidade, Carol...", identificando o desenvolvimento do seu olhar, "gosto de como compartilhamos nossos olhares aqui, de como cada um aprende olhando e criticando a foto de cada colega", assim como, auferir possibilidades de um criar no qual antes não eram percebidas. 


\section{Considerações finais}

Fomos desafiados a identificar pistas na articulação entre o campo teórico e empírico analisando as imagens compartilhadas na mídia social enquanto construção do conhecimento. Estar juntos em rede nos conduziu a identificar o desenvolvimento de suas representações em interação a cada nova construção imagética. Percebemos que a proposta pedagógica e o compartilhar promoveu um exercício de reflexão, conduzindo os acadêmicos a uma crítica sobre "si", externando dificuldades, aprendizados, medos, experiências e descobertas.

Percebemos suas identidades em estado de construção livre e inacabada, um vir a ser ora individual e ora coletivo. Construíram conhecimento não só pelo seu olhar, mas pelo olhar do "outro", incitando suas capacidades e habilidades como sujeitos/atores e também como aprendentes. Ampliaram os fluxos de interação em um novo sentir, constituindo laços sociais que despertaram o sentimento de pertencimento ao grupo a qual participavam.

Nesse espaço digital virtual - ciberespaço - configuraram a convivência, praticaram a comunicação em rede e estabeleceram normas de condutas sociais, profissionais e acadêmicas - a cibercultura - engendrando relações, identidades, pensamentos, imaginários e valores. Trocaram olhares, aprenderam com a diversidade, conectaram-se pelo olhar sem barreiras, assumiram novos papéis — representações do seu "eu" - enquanto sujeitos/atores, narradores e coatores. Performatizaram para "si" e para os "outros", fazendo parte ora do espetáculo e ora da plateia no palco da vida cotidiana e enquanto usuários midiáticos.

Identificamos também, em todo esse desdobramento, que passaram a refletir e construir "o seu próprio perfil" — atitudes e modos de ser — seu modo de "estar" em relação ao mundo, em relação aos "outros" e a "si" mesmo.

Neste interim, tanto os acadêmicos em evidência quanto a educadora sofreram transformações em seu "eu" individual — identidade — que (re)analisou comportamentos que corroboraram para a construção do conhecimento conforme as experiências foram emergindo entre viver e conviver, socializar e interagir entre os "outros" no coletivo. 


\section{REFERÊNCIAS}

AGAMBEN, Giorgio. Infância e história, destruição da experiência e origem da história. Belo Horizonte: UFMG, 2005.

BAKTHIN, Mikhail. Marxismo e filosofia da linguagem. 6. ed. São Paulo: Hucitec, 1992.

CASTELLS, Manuel. A Sociedade em Rede. São Paulo: Paz e terra, 2007.

LÉVY, P. Cibercultura. Rio de Janeiro: Ed. 34, 1999.

MAFFESOLI, Michel. O imaginário é uma realidade. Revista Famecos. Mídia cultura e tecnologia. № 15, Porto Alegre: EDIPUCRS, p.74-81, ago. 2001a.

NOVAES, Sylvia Caiuby. Jogo de Espelhos. São Paulo: Edusp, 1993.

PAIVA, Cláudio Cardoso de. Elementos para uma epistemologia da cultura midiática. In.: Culturas midiáticas - Revista do programa de Pós-graduação em Comunicação da Universidade Federal da Paraíba. Ano I, n.1 (jul. - dez.). João Pessoa, 2008.

PEIRCE, Charles Sander. Collected Papers of Charles Sanders Peirce. Ed. by: C. Hartshorne \& P. Weiss (v. 1-6); A. Burks (v. 7-8). Cambridge, MA: Harvard University Press, 1931.

PRIMO, A. Interação mútua e interação narrativa. Revista da FAMECOS, v. 07, nº 12, 2008.

PUTNAM, R. D. Bowling Alone: The collapse and Revival of American Community. New York: Simon e Schuster, 2000.

RECUERO, Raquel. A internet e a nova revolução na comunicação mundial. Pontifícia Universidade Católica do Rio Grande do Sul (PUC/RS) em dezembro de 2000.

Redes Sociais na Internet. Porto Alegre, Sulina, 2009.

SANTAELLA, Maria Lucia. Da cultura das mídias à cibercultura: o advento do pós-humano. Revista FAMECOS. Porto Alegre, $n^{\circ}$ 22, p. 23-32, dezembro 2003.

O que é semiótica. Editora Brasiliense, 2012.

SARTRE, Jean Paul. O ser e o nada: ensaio de ontologia fenomenológica. Petrópolis: Vozes (2000).

Data de Recebimento: 19/08/2019

Data de Aprovação: 06/01/2020 


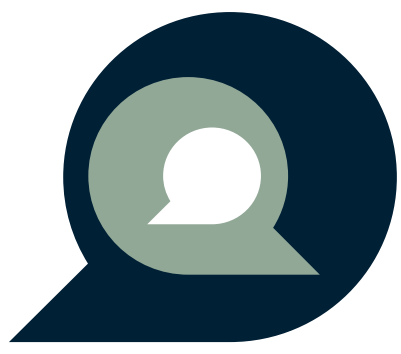

